\title{
Structural variables of macrozoobenthos during stabilization and increase of the Small Aral Sea's level (1996-2008).
}

\author{
Krupa EG ${ }^{1 *}$, Grishaeva $\mathrm{OV}^{2}$, Balymbetov $\mathrm{KS}^{3}$ \\ ${ }^{1}$ Kazakh Agency of Applied Ecology, Amangeldy 70a, Almaty, Kazakhstan \\ ${ }^{2}$ Kazakh-Russian International University, Aktobe, St. Aiteke bi, Kazakhstan \\ ${ }^{3}$ Aral Branch, Kazakh Research Institute of Fisheries, Kazakhstan
}

\begin{abstract}
The purpose of this work was to study the macrozoobenthos of the Small Aral Sea in the period from 1996 to 2008, which was characterized by stabilization and then by a steady increase in the water level and decrease in water salinity. Samples of macrozoobenthos were taken in the Small Aral Sea using a grid of 20 stations. During the study period, the average salinity of water varied from $6.3 \%$ to $19.0 \%$. 10 taxa were identified in the benthic community. The average annual abundance of macrozoobenthos was 1962 species $/ \mathrm{m}^{2}$, with its biomass at 83.3 $\mathrm{g} / \mathrm{m}^{2}$. Quantitative variables of the community were primarily formed by polychaete Hediste diversicolor, mollusks Abra ovata, Caspiohydrobia sp. and Cerastoderma isthmicum. During the period of study, abundance and biomass of macrozoobenthos decreased by an order of magnitude from 4274 to $641 \mathrm{species} / \mathrm{m}^{2}$ and from 206.0 to $20.6 \mathrm{~g} / \mathrm{m}^{2}$, respectively. The average values of the Shannon index - $1.20 \mathrm{bits} / \mathrm{specimen}$ and $0.92 \mathrm{bits} / \mathrm{mg}$, were characteristic of a low diversity of benthic cenosis. Evidently, the water salinity had a positive effect on the long-term dynamics of macrozoobenthos biomass. The observed decrease in the quantitative variables of macrozoobenthos during desalination of the Small Aral Sea is not only due to the deterioration of hydrochemical conditions for marine and halophilic species, but also to the increased pressure on the benthic fauna caused by fish.
\end{abstract}

Keywords: Small Aral Sea, benthic invertebrates, hydrological regime, sea level, salinity, Kazakhstan, dynamics.

Accepted on February 04, 2019

\section{Introduction}

The Aral Sea is an inland water body with no connection to the ocean [1]. It is characterized by shallow water and strong desalination due to the pronounced influence of atmospheric processes and river runoff. These features cause a great variability of hydrological, hydrochemical and biological variables of the Aral Sea under the influence of external conditions.

Until 1961, during the quasi-stable period, the water level of the Aral Sea varied within relatively small limits. At the level of $53.4 \mathrm{~m}$ Baltic System (BS), surface area was $68900 \mathrm{~km}^{2}$, the volume of water was 78.2 thousand $\mathrm{km}^{3}$, with the maximum depth of $18.0 \mathrm{~m}$ and an average depth of $8.7 \mathrm{~m} \mathrm{[2].} \mathrm{The} \mathrm{average} \mathrm{salinity}$ of water during this period changed marginally from 9.7 to 10.2 . In the following decades, due to disruption of water balance, the sea level decreased from 53.4 to $39.0 \mathrm{~m} \mathrm{BS}$, and salinity increased to 58.0 [3]. In 1988-1989, the sea was divided into two isolated partsthe Small and Large Aral. In 2005, in order to restore the northern part of the sea, a dam was built in the Berg's Strait, preventing the flow of the Syrdarya River to the Great Aral Sea. This led to an increase in the level of the Small Aral to $42.5 \mathrm{~m}$ and a decrease in the average salinity of water to $12.9 \%$ [4]. The salinity of the Big Aral, which by 2010 was divided into several isolated hypersaline water bodies, continued to grow and exceeded $150 \%$ by the end of the 1990s [5].

In the period of the natural hydrological regime, the benthic fauna was studied throughout the entire floor of the Aral Sea [6-10]. After the division of the sea, mainly the northern part of the sea, the Small Aral was under constant observation [1115]. The above-listed works provide information on the species composition and quantitative parameters of benthic invertebrates in the quasi-stable and subsequent period of degradation of the Aral Sea. The dramatic consequences of salinization of the marine ecosystem, that caused the extinction of a number of freshwater and brackish-water species from various systematic groups, are shown. There is data of the structure of benthic cenoses in the subsequent period of stabilization of the level of the Small Aral [16-18], which was due to favorable weather conditions of 1988-1994.

The purpose of this work was to study the macrozoobenthos of the Small Aral Sea in the period from 1996 to 2008, which was characterized by stabilization and then by a steady increase in the water level and decrease in water salinity.

\section{Description of the Study Area}

The Aral Sea is located in the arid climatic zone, with an average annual precipitation of up to $100-115 \mathrm{~mm}$ and a temperature gradient from $-36^{\circ} \mathrm{C}$ to $+43^{\circ} \mathrm{C}$ [19]. Until the second half of the $20^{\text {th }}$ century, the Aral Sea was the largest brackish water body in Central Asia. The complex of anthropogenic and natural factors caused a significant reduction in the water surface area and the division of a single water area into two 
isolated parts, the Small and the Large Aral [18]. Starting from 1988-1989, the succession of the northern and southern parts of the sea occurs independently of each other.

The Small Aral Sea has a highly dissected coastline forming three large bays - Shevchenko in the west, Butakova in the north and Saryshyganak in the northeast (Figure 1). The main feeding artery of the Small Aral is the Syrdarya River. It is formed at the confluence of Naryn and Karadarya rivers in the eastern part of the Fergana Valley in Uzbekistan. The river is predominantly fed by snow, to a lesser extent, by glacier and rain water [20]. The river is controlled by five large reservoirs, including the Shardara Reservoir on the territory of Kazakhstan. The flow of the Syrdarya River is determined by the climatic conditions of the year, the regime of filling and draining the Shardara Reservoir, as well as the amount of water taken in for crop irrigation.

The Syrdarya River's flow volume, along with natural factors, causes changes in the morphometric and hydrochemical parameters of the Small Aral Sea. During quasi-stable period (1930-1960s), the surface area of the Small Aral Sea reached $3300 \mathrm{~km}^{2}$ [21]. The Syrdarya River's flow volume during these years was estimated at $9.9-21.3 \mathrm{~km}^{3}$ [3]. The intensive intake of river water for irrigation of agricultural crops led to the shallowing of the sea in subsequent years $[21,22]$. The most catastrophic decrease in the flow of the Syrdarya River - 0.2-0.3 $\mathrm{km}^{3}$ was observed in 1973-1977. In 1987-2010, the volume of water in the Small Aral Sea varied from 2.0 to $17.9 \mathrm{~km}^{3}$ [3].

In the study period of 1996-2008, the water level of the Small
Aral Sea varied from 39.0 to $42.1 \mathrm{~m}$ BS. The average depth of the sea reached $5.0 \mathrm{~m}$. Shevchenko Bay, as well as the central and northeastern parts of the water area, were characterized by the greatest depths and transparency of the water (Table 1). The values of these parameters, as well as the water temperature, were minimal in the zone of influence of the Syrdarya River. The predominant types of soil were dark gray silt and sand.

\section{Materials and Methods}

Samples of macrozoobenthos were taken by a small Petersen grab in the summer of 1996-2008, in the spring of 2002-2004 and in the autumn of 2006, according to a standard grid of 20 stations covering the entire water area of the Small Aral Sea (Figure 1). A total of 160 macrozoobenthos samples were processed. At each station, the depth, transparency, water temperature, predominant type of soil were determined. To determine the chemical composition and total dissolved salts, water samples were taken into plastic containers with a volume of $1 \mathrm{~L}$.

Conventional methods of chemical analysis of water were used [23]. Water samples were analyzed in three-four replications. The error of estimate for major ions in the water was $0.5 \%-5.0 \%$, depending on the analysis. Macrozoobenthos samples were processed according to generally accepted methods [24] using determinants for corresponding groups [2528]. The average values with a standard error were calculated for all variables in Excel. The Shannon Index values (Shannon $\mathrm{Ab}$, Shannon Bi), characterizing the diversity of biological communities [29], were calculated in Primer 5 program. To

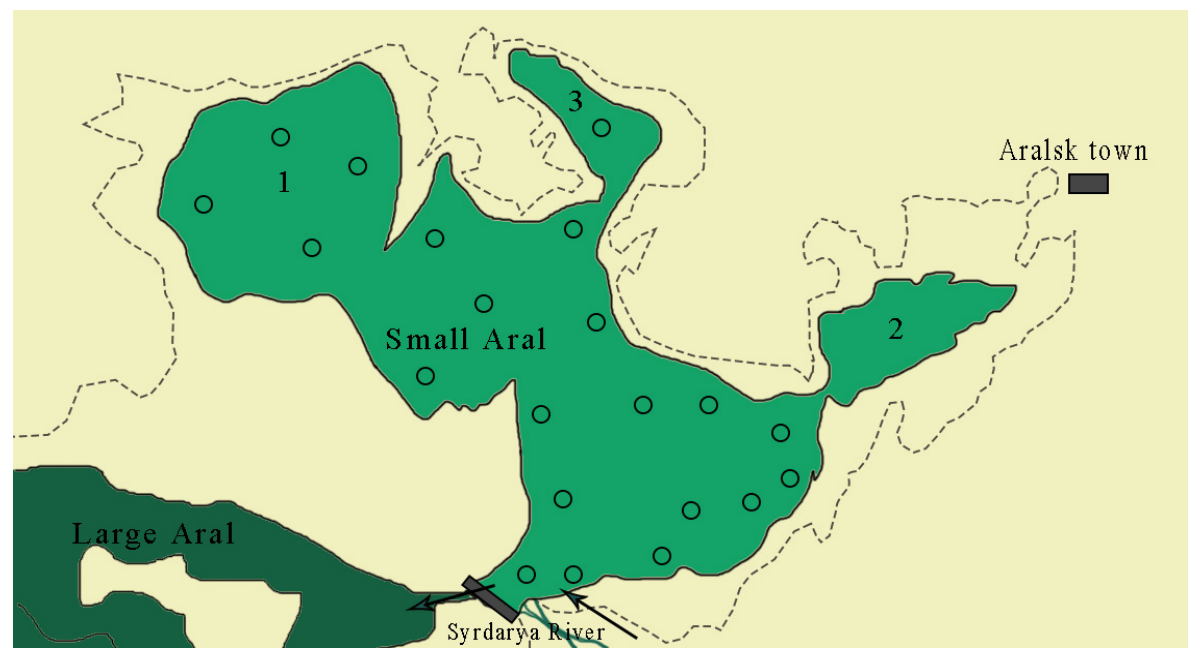

Figure 1. Map of macrozoobenthos sampling in the Small Aral Sea

The dashed line indicates the outline of the Small Aral during the quasi-stable state of the level.

Circles - macrozoobenthos sampling stations. Arrows - the direction of movement of water masses.

The numbers indicate the bays: 1. Shevchenko, 2. Saryshyganak, 3. Butakova

Table 1. Hydrophysical variables and the predominant types of soil of the Small Aral Sea

\begin{tabular}{|l|c|c|c|}
\hline \multirow{2}{*}{ Part of the sea } & \multicolumn{2}{|c|}{ Hydrophysical variables } & Types of soil \\
\cline { 2 - 4 } & Depth, $\mathbf{m}$ & Transparency, $\mathbf{m}$ & Water temperature, ${ }^{\circ} \mathbf{C}$ \\
\hline Shevchenko Bay & 11.5 & 1.7 & 17.7 \\
\hline Butakova Bay & 4.4 & 1.8 & 21.8 \\
\hline Centre & 7.8 & 1.6 & 22.4 \\
\hline North-eastern & 6.9 & 1.5 & Dark gray and Gray silt, sand \\
\hline Near the mouth of the Syrdarya & 2.6 & 0.8 & 21.5 \\
\hline
\end{tabular}


assess the effect of water salinity on the quantitative variables of macrozoobenthos, Spearman's rank correlation coefficients were calculated in Statistica 10.

\section{Results}

\section{Hydrochemical characteristics of the Small Aral Sea}

Fluctuations of the sea level caused significant changes in salinity and chemical composition of waters (Table 2). The maximum values of the variable were observed at the beginning of the analyzed period. After the construction of a permanent dam in the Berg's Strait in 2005, the average salinity of sea water decreased. Generally, water salinity in summer was higher than in the spring. Regarding the chemical composition, water belongs to the chloride or sulphate class, the sodium group. The ratio of chloride and sulfate ions varied in different years, but was not directly related to the salinity of water. So, at similar values of salinity, in 2005 sulfate ions prevailed, while in 2008 there were more chloride ions. Similar instability of chemical composition of water was recorded during other periods of observation.

\section{Macrozoobenthos of the Small Aral Sea}

10 taxa of macrozoobenthos were identified (Table 3). Only three species were encountered constantly - the polychaete Hediste diversicolor, mollusks Abra ovata and Cerastoderma isthmicum. In 2007, polychaete was distributed throughout the entire water area, including the zone near the river mouth and almost completely dry Saryshyganak Bay. Until 2005, mollusk A. ovata was found throughout the water area. In 20062007 , with a decrease in salinity of sea waters, this species became rare in the estuarine zone, although it was still widely distributed throughout the rest of the water area. In certain years, the bivalve mollusk $C$. isthmicum was recorded in all areas of the sea, excluding the desalinated zone. In 2004, gastropod Caspiohydrobia sp. disappeared from of the benthic community of the desalinated estuarine area. In 2007-2008, this species was found only in the western part of the sea. Other species of benthic invertebrates were rare. Oligochaetes, leeches, chironomids Procladius ferrugineus, Chironomus behningi, mollusk Theodoxus pallasi, prawn Palaemon elegans, mysid Paramysis (Mesomysis) lacustris were found sporadically in the desalinated areas of the sea.

With relatively stable species composition, the quantitative variables of macrozoobenthos varied significantly from year to year (Table 4). The maximum values of abundance and biomass of the benthic community were recorded at the beginning of the analyzed period (1996-2002), with their subsequent decrease against the background of desalination. Statistical analysis of the available data showed that the salinity of water had a statistically significant effect on the biomass of the benthic community, with the Spearman correlation coefficient $\mathrm{R}=0.75$

Table 2. Salinity and chemical composition of the water of the Small Aral Sea

\begin{tabular}{|c|c|c|c|c|c|c|c|}
\hline \multirow{2}{*}{ Year, month } & \multirow{2}{*}{ Salinity, \% } & \multicolumn{6}{|c|}{ Ion concentration, $\mathrm{g} / \mathrm{dm}^{3}$} \\
\hline & & $\mathrm{Ca}^{2+}$ & $\mathrm{Mg}^{2+}$ & $\mathrm{Na}^{++} \mathrm{K}^{+}$ & $\mathrm{HCO}_{3}^{-}$ & $\mathrm{SO}_{4}^{2-}$ & $\mathrm{Cl}^{-}$ \\
\hline 1996, June & 20.4 & - & - & - & - & - & - \\
\hline 1997, June & 19.0 & - & - & - & - & - & - \\
\hline 1998, June & 14.5 & - & - & - & - & - & - \\
\hline 2001, June & 18.6 & 0.7 & 1.1 & 4.3 & 0.2 & 5.4 & 6.2 \\
\hline 2002, June & 15.1 & 0.4 & 0.7 & 3.7 & 0.2 & 4.7 & 4.7 \\
\hline 2004, August & 13.9 & 0.1 & 0.1 & 4.8 & 0.3 & 4.6 & 3.5 \\
\hline 2005, May-June & 10.8 & 0.4 & 0.7 & 2.3 & 0.2 & 3.7 & 3.1 \\
\hline 2006, May-June & 8.9 & - & - & - & - & - & - \\
\hline 2006, July-September & 11.2 & - & - & - & - & - & - \\
\hline 2007, May-June & 6.3 & 0.4 & 0.5 & 1.0 & 0.2 & 1.6 & 2.4 \\
\hline 2007, August-September & 10.5 & - & - & - & - & - & - \\
\hline 2008, June-July & 11.8 & 0.5 & 0.6 & 3.0 & 0.9 & 3.3 & 3.5 \\
\hline
\end{tabular}

Table 3. Taxonomic composition and frequency of occurrence of benthic invertebrates of the Small Aral Sea

\begin{tabular}{|c|c|c|c|c|c|c|c|c|}
\hline \multirow{2}{*}{ Taxon Name } & \multicolumn{8}{|c|}{ Frequency of Occurrence, \% } \\
\hline & 2001 & 2002 & 2003 & 2004 & 2005 & 2006 & 2007 & 2008 \\
\hline \multicolumn{9}{|l|}{ Phylum Annelides } \\
\hline Oligochaeta gen. sp. & 15 & - & - & - & - & - & - & - \\
\hline Hediste diversicolor Muller & 80 & 90 & 100 & 85 & 86 & 80 & 55 & 75 \\
\hline \multicolumn{9}{|c|}{ Phylum Arthropoda, Subphylum Crustacea } \\
\hline Dikerogammarus aralensis Uljanin & - & - & 5 & - & - & - & - & - \\
\hline Paramysis lacustris Czerniavsky & - & - & - & - & 5 & - & - & - \\
\hline Palaemon elegans Rathke & - & - & - & 5 & - & - & - & - \\
\hline \multicolumn{9}{|c|}{ Subphylum Tracheata, Superclass Insecta } \\
\hline Chironomus behningi Goetghebuer & - & 5 & 25 & - & 5 & 35 & 9 & 25 \\
\hline \multicolumn{9}{|l|}{ Phylum Mollusca } \\
\hline Cerastoderma isthmicum Issel & 50 & 50 & 40 & 45 & 43 & 15 & 9 & 45 \\
\hline Abra ovata Philippi & 70 & 65 & 55 & 70 & 52 & 50 & 59 & 70 \\
\hline Caspiohydrobia sp. & 35 & 55 & 80 & 20 & 5 & - & 5 & 5 \\
\hline Theodoxus pallasi Lindholm & 30 & 5 & - & 10 & - & - & - & - \\
\hline Всего: & 6 & 6 & 6 & 6 & 6 & 4 & 5 & 5 \\
\hline
\end{tabular}


Citation: Krupa EG, Grishaeva OV, Balymbetov KS. Structural variables of macrozoobenthos during stabilization and increase of the Small Aral Sea's level (1996-2008). J Fish Res. 2019;3(1):1-6.

Table 4. The long-term dynamics of the abundance and biomass of the dominant species and the whole macrozoobenthos of the Small Aral Sea.

\begin{tabular}{|c|c|c|c|c|c|c|}
\hline \multirow{2}{*}{ Year } & H. diversicolor & A. ovata & C. isthmicum & Caspiohydrobia sp. & Others & Total \\
\hline & \multicolumn{6}{|c|}{ Abundance, $\mathrm{spec} . / \mathrm{m}^{2}$} \\
\hline 2001 & $578 \pm 172$ & $3174 \pm 1031$ & $180 \pm 63$ & $294 \pm 89$ & $46 \pm 19$ & $4274 \pm 1229$ \\
\hline 2002 & $1342 \pm 261$ & $2606 \pm 888$ & $264 \pm 114$ & $324 \pm 140$ & $4 \pm 2$ & $4540 \pm 1084$ \\
\hline 2003 & $770 \pm 105$ & $1094 \pm 650$ & $105 \pm 47$ & $1302 \pm 913$ & $50 \pm 21$ & $3321 \pm 1600$ \\
\hline 2004 & $292 \pm 104$ & $544 \pm 182$ & $154 \pm 56$ & $18 \pm 10$ & $6 \pm 4$ & $1014 \pm 307$ \\
\hline 2005 & $339 \pm 94$ & $366 \pm 194$ & $70 \pm 33$ & $2 \pm 2$ & $4 \pm 3$ & $781 \pm 210$ \\
\hline 2006 & $167 \pm 51$ & $359 \pm 208$ & $96 \pm 82$ & $0 \pm 0$ & $59 \pm 24$ & $681 \pm 261$ \\
\hline 2007 & $194 \pm 55$ & $230 \pm 71$ & $4 \pm 3$ & $2 \pm 2$ & $12 \pm 8$ & $442 \pm 73$ \\
\hline 2008 & $170 \pm 28$ & $318 \pm 87$ & $89 \pm 35$ & $22 \pm 18$ & $42 \pm 21$ & $641 \pm 140$ \\
\hline Average & $482 \pm 144$ & $1086 \pm 408$ & $120 \pm 28$ & $246 \pm 158$ & $28 \pm 8$ & $1962 \pm 624$ \\
\hline \multicolumn{7}{|c|}{ Biomass, $\mathbf{g} / \mathbf{m}^{2}$} \\
\hline 1996 & $8.1 \pm 1.6$ & $90.0 \pm 27.5$ & $70.4 \pm 22.8$ & $1.1 \pm 0.3$ & $0.06 \pm 0.02$ & $169.7 \pm 43.9$ \\
\hline 1997 & $6.6 \pm 1.2$ & $80.8 \pm 30.2$ & $37.3 \pm 18.0$ & $0.5 \pm 0.2$ & $0.02 \pm 0.01$ & $125.2 \pm 40.7$ \\
\hline 1998 & $8.8 \pm 1.6$ & $101.8 \pm 36.4$ & $22.4 \pm 12.6$ & $1.1 \pm 0.6$ & $0.08 \pm 0.04$ & $134.2 \pm 40.0$ \\
\hline 2000 & $3.9 \pm 0.9$ & $130.4 \pm 25.6$ & $53.9 \pm 35.3$ & $1.5 \pm 0.6$ & $0.0 \pm 0.0$ & $189.7 \pm 41.9$ \\
\hline 2001 & $5.8 \pm 2.2$ & $138.0 \pm 36.8$ & $18.6 \pm 15.7$ & $1.2 \pm 0.4$ & $0.3 \pm 0.2$ & $206.7 \pm 48.7$ \\
\hline 2002 & $7.8 \pm 2.0$ & $135.0 \pm 39.7$ & $47.8 \pm 15.4$ & $1.4 \pm 0.6$ & $0.04 \pm 0.2$ & $192.1 \pm 53.8$ \\
\hline 2003 & $4.1 \pm 0.7$ & $50.8 \pm 24.5$ & $14.0 \pm 7.3$ & $25.4 \pm 24.6$ & $0.4 \pm 0.2$ & $94.7 \pm 50.2$ \\
\hline 2004 & $1.3 \pm 0.4$ & $33.6 \pm 14.7$ & $15.3 \pm 6.7$ & $0.1 \pm 0.04$ & $0.2 \pm 0.2$ & $50.4 \pm 18.6$ \\
\hline 2005 & $2.6 \pm 0.6$ & $19.5 \pm 9.8$ & $18.5 \pm 8.7$ & $0.01 \pm 0.01$ & $0.04 \pm 0.2$ & $40.7 \pm 17.0$ \\
\hline 2006 & $1.1 \pm 0.3$ & $19.5 \pm 8.0$ & $17.5 \pm 11.2$ & $0 \pm 0$ & $0.5 \pm 0.2$ & $38.6 \pm 15.0$ \\
\hline 2007 & $3.4 \pm 1.2$ & $18.4 \pm 5.3$ & $0.5 \pm 0.4$ & $0.01 \pm 0.01$ & $0.01 \pm 0.1$ & $22.3 \pm 5.1$ \\
\hline 2008 & $4.2 \pm 0.7$ & $12.0 \pm 3.5$ & $4.0 \pm 1.7$ & $0.2 \pm 0.2$ & $0.02 \pm 0.2$ & $20.6 \pm 4.9$ \\
\hline Average & $3.8 \pm 0.8$ & $53.4 \pm 18.6$ & $17.0 \pm 5.0$ & $3.5 \pm 3.1$ & $0.2 \pm 0.1$ & $83.3 \pm 26.6$ \\
\hline
\end{tabular}

and $\mathrm{p}<0.05$.

The main part of quantitative variables of the community was formed by the background species listed above. The absolute leader during the observation period, except for 2003, was the bivalve $A$. ovata. It accounted for $46-60 \%$ of the abundance and $54-83 \%$ of the macrozoobenthos biomass. $H$. diversicolor and $C$. isthmicum were on the second place. In the perennial dynamics, there was a declining trend of the mollusk C. isthmicum in the total abundance (from $15 \%$ to $1 \%$ ) and biomass (from $25 \%$ to $2 \%$ ) of the benthic community.

To define the diversity of benthic community, the Shannon index was calculated. The average values of the diversity index, calculated by the share of species in the total abundance (Shannon
$\mathrm{Ab}$ ) and the biomass of the community (Shannon Bi), over a number of years changed synchronously (Figure 2). The maximum values of both indices occurred in 2008, the minimum in 2007. According to the average perennial values of the Shannon index $(1.20 \pm 0.05 \mathrm{bits} / \mathrm{specimen}$ and $0.92 \pm 0.07 \mathrm{bits} / \mathrm{mg})$ the diversity of macrozoobenthos in the analyzed period was very low.

\section{Discussion}

The fauna of any water body is determined primarily by the salinity of water [30,31]. During our studies, with an average salinity of $6.3 \%-19.0 \%$, the macrozoobenthos of the Small Aral Sea was represented by 10 taxa. This is significantly less than in the quasi-stable period, when macrozoobenthos included 39 species at an average salinity of $10.0 \%$ [10]. The background

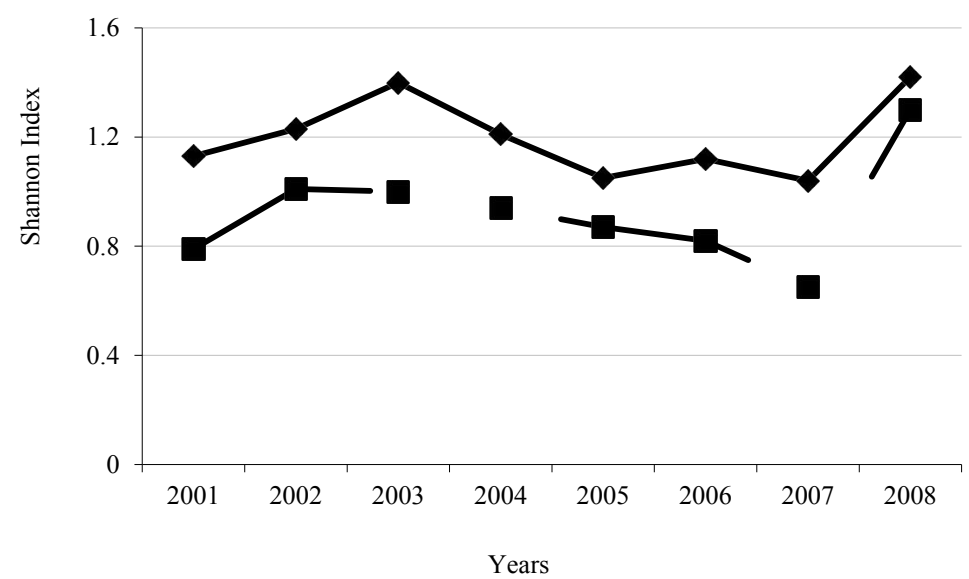

$\longrightarrow$ Shannon $\mathrm{Ab} \longrightarrow$ Shannon $\mathrm{Bi}$

Figure 2. The long-term dynamics of the diversity of macrozoobenthos of the Small Aral Sea according to the Shannon index. 
Table 5. Changes in the average values of macrozoobenthos biomass of the Aral Sea in different periods of its existence.

\begin{tabular}{|l|c|c|c|c|c|}
\hline \multirow{2}{*}{ Period } & Years & \multicolumn{3}{|c|}{ Salinity, \% } & \multicolumn{2}{c|}{ Macrozoobenthos Biomass, g/m ${ }^{\mathbf{2}}$} \\
\cline { 2 - 5 } & & Average & Min-Max & $22.8 \pm 1.5$ \\
\hline Quasi-stable & $1933-1964[39]$ & $10.1 \pm 0.2$ & $9.0-10.9$ & $124.0 \pm 14.9$ \\
\hline Salinization & $1961-1991[10,39]$ & $17.9 \pm 2.4$ & $11.5-33.8$ & $17.9-40.6$ \\
\hline Stabilization & $1992-2002[10]$ & $19.6 \pm 1.4$ & $14.5-28.7$ & $33.1-372.5$ \\
\hline Desalination & $2003-2008$ & $10.7 \pm 0.8$ & $6.3-12.9$ & $125.3-246.0$ & $42.1 \pm 10.0$ \\
\hline
\end{tabular}

Note: 1933, 1986-2009 - Data is of Small Aral Sea only; Other years - Data is of entire water area of the sea.

species were polychaeta Hediste devirsicolor Muller, amphipod Dikerogammarus aralensis Uljanin, Chironomidae larvae, mollusks of the genera Dreissena, Cerastoderma, Caspiohydrobia, Abra, Hypanis, Theodoxus. Primary depletion in species composition of benthic invertebrates occurred at a salinity of $11.6 \%-13.7 \%$ [18,32,33]. Upon further salinization of the sea to $25 \%-28 \%$, only species of marine origin - Hediste diversicolor, Abra ovata, Cerastoderma isthmicum, Palaemon elegans, Rhitropanopeus harrisi and halophilic representatives of the genus Caspiohydrobia sp. remained in macrozoobenthos.

On average for 1996-2008, the abundance of macrozoobenthos was 1962 species $/ \mathrm{m}^{2}$, with a biomass of $83.3 \mathrm{~g} / \mathrm{m}^{2}$. Polychaete $H$. diversicolor, mollusks $A$. ovata and C. isthmicum, in some years together with Caspiohydrobia sp. were dominant. Against the background of desalination of the Small Aral Sea from beginning to end of the observation period, the values of both parameters decreased by an order of magnitude from 4274 to 641 species $/ \mathrm{m}^{2}$ and from 206.0 to 20.6 $\mathrm{g} / \mathrm{m}^{2}$, respectively. When analyzing both our own and literature data (Table 5), we observed the positive effect of water salinity on the long-term dynamics of macrozoobenthos biomass. This is due to the dominance of the above-mentioned marine and euryhaline species in the benthic community. The polychaete $H$. diversicolor and the mollusk $A$. ovata were introduced into the Aral Sea in the 1960s and soon became one of the widespread species of benthic invertebrates [10]. For these introduced species, as well as for the aboriginal mollusk C. isthmicum, the increase in salinity, which began in the late 1960s - early $70 \mathrm{~s}$, turned out to be extremely favorable [34,35]. The decrease in the quantitative variables of macrozoobenthos during the desalination of the Small Aral Sea is explained not only by the deterioration of hydrochemical conditions for marine and halophilic species, but also by the increased pressure of fish on the benthic fauna [36].

It is likely that the observed decrease in the number and biomass of macrozoobenthos is only one of the stages of changing of the community structure. If the planned increase in the crest of Dike Kokaral by 6-8 $\mathrm{m}$ is done, a further decrease in the average salinity of the northern part of the sea will occur. As the level rises, the area of the desalinated water area will significantly expand, which will be a negative factor for marine and euryhaline species. Desalination will contribute to the emergence of the generative freshwater and brackish-water species in the benthic community of the Small Aral Sea, which currently remain in the delta of Syrdarya and its floodplain lakes [37,38].

\section{Conclusion}

In 1996-2008, the macrozoobenthos of the Small Aral Sea was represented by 10 taxa. The long-term average annual abundance of benthic invertebrates was 1962 species $/ \mathrm{m}^{2}$, with a biomass of $83.3 \mathrm{~g} / \mathrm{m}^{2}$. Marine and euryhaline species were prevalent - polychaete $H$. diversicolor, mollusks $A$. ovata and C. isthmicum, in some years together with Caspiohydrobia sp. Against the background of desalination of the Small Aral Sea from $18.6-20.4 \%$ to $6.3 \%-11.8 \%$, the quantitative variables of the community decreased by an order of magnitude from 4274 to $641 \mathrm{species} / \mathrm{m}^{2}$ and from 206.0 to $20.6 \mathrm{~g} / \mathrm{m}^{2}$. According to the values of the Shannon index $-1.20 \mathrm{bits} / \mathrm{specimen}$ and 0.92 bits/mg - the diversity of macrozoobenthos in the analyzed period was very low. The positive relationship between the long-term variability of water salinity and quantitative variables of macrozoobenthos was due to the dominance of species of marine origin in its composition. The observed decrease in the quantitative variables of macrozoobenthos during the desalination of the Small Aral Sea is explained not only by the deterioration of hydrochemical conditions for marine and halophilic species, but also by the increased pressure of fish on the benthic fauna.

\section{References}

1. Dobrovolsky AD, Zalogin BS. Sea of the USSR. Moscow State University. Moscow. 1982.

2. Micklin P. The Aral Sea. Springer Earth System Sciences. Springer-Verlag. Heidelberg. Berlin. 2014.

3. Gaybullaev B, Chen SC, Gaybullaev D. Changes in water volume of the Aral Sea after 1960. Appl Water Sci. 2012;2:285-91.

4. Krupa EG, Grishaeva OV. The structure of species dominance in the macrozoobenthos of the Small Aral Sea as an indicator of changes in water salinity. Bioindication in monitoring freshwater ecosystems. Saint Petersburg. 2011;96.

5. Aladin NV, Plotnikov IS. Modern fauna of residual water bodies formed on the place of the former Aral Sea. Proceedings of the Zoological Institute of the Russian Academy of Sciences. 2008;312(1/2):145-54.

6. Beklemishev VN. New data on the fauna of the Aral Sea. Hydrobiol J. 1922;9(10):276-88.

7. Sidorov SA. Mollusks of Aral and its immediate surroundings. Hydrobiol J. 1929;8(1-3):13-37.

8. Kichagov LV. About the feed base of the Aral Sea. Fisheries. 1937;3:47-8.

9. Gavrilov GB. Distribution of oligochaetes in the Aral Sea 
Citation: Krupa EG, Grishaeva OV, Balymbetov KS. Structural variables of macrozoobenthos during stabilization and increase of the Small Aral Sea's level (1996-2008). J Fish Res. 2019;3(1):1-6.

for navigation in 1964. Fish resources of Kazakhstan's water bodies and their use. Science of the Kazakh SSR. 1970;6:32-6.

10. Andreev NI. Hydro-fauna of the Aral Sea in conditions of environmental crisis. Omsk. 1999.

11. Andreev NI, Andreeva SI. Bottom biocenoses of the Aral Sea when its regime changes. Hydrobiol J. 1987;23(5):81-6.

12. Andreeva SI. The modern Cerastoderma (Bivalvia, Cardiidae) of the Aral Sea. Omsk. 2000.

13. Andreev NI, Andreeva SI, Filippov AA. Zoobenthos of the Aral Sea under conditions of progressive salinization. The current state of the Aral Sea in the context of progressive salinization. Leningrad. 1990;223:24-9.

14. Aladin NV. Study of the effect of salinization of the waters of the detached bays of the Aral Sea on the aquatic species. The current state of the detached bays of the Aral Sea. Leningrad. 1991;237:4-12.

15. Aladin N, Micklin P, Plotnikov I. Biodiversity of the Aral Sea and its importance to the possible ways of rehabilitating and conserving its remnant water bodies. Environmental Problems of Central Asia and their Economic, Social and Security Impacts. Springer Science, Business Media BV. 2008;73-98.

16. Filippov AA. Macrozoobenthos in the inshore zone of the Northern Aral Sea. Int J Salt Lake Res. 1996;5:315.

17. Filippov AA. Macrozoobenthos of the Small Aral Sea. Russ J Mar Biol. 2001;27:401.

18. Aladin N, Filippov A, Plotnikov I, et al. Changes in the structure and function of biological communities in the Aral Sea, with particular reference to the northern part (Small Aral Sea), 1985-1994: A review. Int J Salt Lake Res. 1998;7:301-43.

19. Zhitomirskaya OM. Climatic description of the Aral Sea region. Hydrometeorological Publishing House. Leningrad. 1964.

20. Armstrong RA, Rittger K, Brodzik MJ, et al. Runoff from glacier ice and seasonal snow in High Asia: separating melt water sources in river flow. Reg Environ Change. 2018;1-13.

21. Micklin P. The Aral Sea Disaster. Annu Rev Earth Planet Sci. 2007;35:47-72.

22. Amirgaliev NA. Aral-Syrdarya basin: hydrochemistry, problems of aquatic toxicology. Bastau. 2007.

23. Semenova AD. Guidelines for chemical analysis of surface water. Gidrometeoizdat. Leningrad. Russia. 1977.

24. Barulin Yu A. Guidelines for the collection and processing of materials for hydrobiological studies on freshwater bodies. Zoobenthos and its products. GosNIORH. Leningrad. 1984.

25. Shilova AI. Khironomidy Rybinskogo vodokhranilishcha (Chironomids of the Rybinsk reservoir). Leningrad. Nauka. 1976.
26. Pankratova V Ya. Larvae and pupae of mosquitoes of the subfamily Podonominae and Tanypodinae of the USSR fauna. Enlightenment. Leningrad. 1977.

27. Tsalolikhin SJ. Key to freshwater invertebrates of Russia and adjacent lands. Saint Petersburg. 1995;1.

28. Tsalolikhin SJ. Key to freshwater invertebrates of Russia and adjacent lands. Saint Petersburg. 1995;2.

29. Magurran AE. Ecological diversity and its Measurement. Moscow. 1998.

30. Khlebovich VV. Features of the composition of aquatic fauna depending on the salinity of the environment. J Gen Biol. 1962;23(2):90-7.

31. Khlebovich VV, Aladin NV. The Salinity Factor in Animal Life. Vestnik Rossiǔskoǐ akademii nauk. 2010;80(3):299304.

32. Andreeva SI. Macrobentofauna of the Aral Sea in terms of its modified regime. Abstract of dissertation for the degree of candidate of biological sciences. Moscow. 1984.

33. Plotnikov I. Changes in the species composition of the Aral Sea free-living invertebrates (Metazoa). Proceedings of the Zoological Institute of the Russian Academy of Sciences. 2013;3:41-54.

34. Aladin N, Crétaux JF, Plotnikov IS, et al. Modern hydrobiological state of the Small Aral sea. Environmetrics. 2005;16:375-92.

35. Aladin NV, Plotnikov IS, Micklin P, et al. The Aral Sea: Water level, salinity and long-term changes in biological communities of an endangered ecosystem - past, present and future. Natural Resources and Environmental Issues. 2009;15:177-83.

36. Aladin NV, Gontar VI, Zhakova LV, et al. The zoocenosis of the Aral Sea: six decades of fast-paced change. Environ Sci Pollut Res. 2018;26(3):2228-37.

37. Grishaeva OV. Macrozoobenthos of the Kamyshlybashsky system of lakes. Uzbek Biological Journal. 2010;2:49-52.

38. Balymbetov KS, Grishaeva OV. Hydrobiology of the Syrdarya River (downstream) in 2005-2007. Ecology and hydrofauna of water bodies of the transboundary basins of Kazakhstan. Almaty. 2008;125-34.

39. Yablonskaya EA, Kortunova TA, Gavrilov GB. Perennial changes in the Aral Sea benthos. Proceedings of All-Union Scientific Research Institute of Marine Fisheries and Oceanography. 1973;80:147-58.

\section{*Correspondence to:}

Krupa EG

Kazakh Agency of Applied Ecology

Amangeldy 70a

Almaty

Kazakhstan

050012

E-mail: elena_krupa@mail.ru 